\title{
Legal Protection of Victim Rights Against Human Trafficking in the Criminal Justice Process
}

\author{
Fuad Nur $^{1} \quad$ M. Syukri Akub ${ }^{2} \quad$ M. Said Karim² $\quad$ Syamsuddin Muchtar ${ }^{3}$ \\ 1.Graduate School, Hasanuddin University, Indonesia \\ 2.Professor, Faculty of Law, Hasanuddin University, Indonesia \\ 3.Associate Professor, Faculty of Law, Hasanuddin University, Indonesia
}

\begin{abstract}
The phenomenon of trafficking in persons in Indonesia today is in alarming conditions. Apart from being a source of trafficking in people who are widely exploited abroad, Indonesia has also become an organized destination for trafficking in persons even with corporate involvement. The common forms of exploitation include forced labor or forced service, slavery and slavery-like practices. Forced labor or forced service is a working condition that arises through a method, plan or pattern intended so that someone is sure that if he does not do a certain job, then he or the person who is responsible will suffer both physically and psychologically. The right of citizens to avoid torture, slavery as happened in trafficking in persons is clearly regulated in Article 28I paragraph 1 of the 1945 Constitution of the Republic of Indonesia, and the law which specifically regulates the crime of trafficking in persons is Law No. 21 Year 2007 concerning Eradication of Crime in Trafficking in Persons.
\end{abstract}

Keywords: criminal justice process, human trafficking, legal protection, victim rights.

DOI: $10.7176 / \mathrm{JLPG} / 87-16$

Publication date:July $31^{\text {st }} 2019$

\section{Introduction}

The issue of trafficking in persons is like the "iceberg phenomenon", little is visible on the surface, but in reality not a few are victims. The large number of undetected victims will have an impact on the effectiveness of efforts to eradicate and protect victims of trafficking, especially those crimes against humanity have taken root and are organized in international networks. The phenomenon of trafficking in persons in Indonesia today is in alarming conditions. Apart from being a source of trafficking in people who are widely exploited abroad, Indonesia has also become an organized destination for trafficking in persons even with corporate involvement. This is supported by Indonesia's geographical condition, which is an archipelago (transnational crimes), which includes trafficking in persons.

Indonesia is categorized as a country that has a large number of victims of trafficking in persons spread in various provinces in Indonesia with the dominance of victims being women and children, although it does not rule out the possibility of also victims of men. ${ }^{1}$ The various modus operandi of trafficking crimes, such as the distribution of Indonesian Workers (TKI) abroad with the high lure of income, will increase their interest, especially the promised work does not require special expertise. But without realizing they have entered the trafficking network of people who will be sold abroad to be exploited as unpaid labor or made as women Commercial Sex Workers (PSK) so that their self esteem is deprived of being a god who deserves to be glorified.

The common forms of exploitation include forced labor or forced service, slavery and slavery-like practices. Forced labor or forced service is a working condition that arises through a method, plan or pattern intended so that someone is sure that if he does not do a certain job, then he or the person who is responsible will suffer both physically and psychologically. Slavery is the condition of a person under the ownership of another person and a slavery-like practice is the act of placing someone in the power of another person so that the person is not able to resist a job that is ordered by someone else, even if that person does not want it. ${ }^{2}$ The right of citizens to avoid torture, slavery as happened in trafficking in persons is clearly regulated in Article 28I paragraph 1 of the 1945 Constitution of the Republic of Indonesia, that "the right to life, the right not to be tortured, the right to freedom of mind and conscience, religious rights, the right to not enslaved, the right to be recognized as a person before the law, and the right not to be prosecuted on a retroactive basis are human rights which cannot be reduced under any circumstances".

The law which specifically regulates the crime of trafficking in persons is Law No. 21 Year 2007 concerning Eradication of Criminal Acts on Trafficking in Persons (PTPPO Law). Before the PTPPO Law existed, it did not mean that there had not been any handling of the crimes against humanity. The legal instrument used by law enforcement officers in combating the crime of trafficking in persons before the enactment of the PTPPO Law is to use the Criminal Code (KUHP), Law No. 23 Year 2002 concerning Child

\footnotetext{
${ }^{1}$ Badan Pendidikan dan Pelatihan Kejaksaan Republik Indonesia, 2014. Modul Trafficking. p. 2

${ }^{2} I b i d$, p. 4
} 
Protection, Law No. 13 Year 2006 concerning the Protection of Witnesses and Victims, Law 39 Year 2004 concerning Placement and Protection of Indonesian Migrant Workers Abroad and other legal instruments. The definition of trafficking that seizes a person's rights can be seen in the formulation in Article 1 point 1 of the PTPPO Law, namely "the act of recruiting, transporting, sending, transferring or receiving someone with the threat of violence, the use of violence, kidnapping, confinement, forgery, fraud, misuse of power or vulnerable position, debt trapping or giving payments or benefits, so that the person obtains approval from the person who controls the other person, whether done in the country or between countries, for the purpose of exploitation or causing people to be exploited". And does not rule out the possibility of becoming stateless persons. ${ }^{1}$

This definition emphasizes that trafficking in persons does not have to use violence and intimidation, even with fraud attempts aimed at exploiting victims including trafficking in persons. Whatever form and modus operandi of criminal offenses usually carried out by agents or sponsors of job seekers with various lure of promising jobs but aimed at exploiting is a crime of trafficking in persons. This crime will certainly bring prolonged suffering and harm to various parties, both state, society, family, especially to individuals who are victims. The trafficking arrangements in the Criminal Code can be found in Article 297, namely "the trafficking of immature women and boys is threatened with a maximum imprisonment of 6 years". Unclear trade formulation, the lightness of the criminal threat so that it is considered not commensurate with the suffering of victims of crime and the modus operandi of growing trafficking involving national and international networks so that Article 297 of the Criminal Code is deemed inappropriate as a legal instrument in combating trafficking and protecting trafficking victim's person.

Although there are laws that specifically regulate the eradication of criminal acts of trafficking, a long list of cases of trafficking in persons seems endless. The latest in 2016 which was in the public spotlight was the unfolding of the trafficking syndicate from East Nusa Tenggara (NTT) to Malaysia which added to the long list of TPPO victims in Indonesia. The disclosure of the crime originated from one of the victims of trafficking who was repatriated from Malaysia to his hometown in NTT in a no longer lifeless condition which allegedly hanged himself because depression was not paid by a syndicate of trafficking people who took him to Malaysia. From the results of the development of the National Police, there were 14 suspects and 16 victims of trafficking in persons. $^{2}$

In 2015, the unfolding of human trafficking and slavery on Benjina Island, Aru Islands, Maluku, which involved international networks. As for those involved in the crime, PT. Pusaka Benjina Resources (PT. PBR) where officials and employees are Thai national and also from Indonesia. The victims came from various countries such as Thailand, Myanmar and Cambodia. Finally, in the trial, the Tual District Court (PN Tual) judge sentenced him to 3 years in prison for eight defendants in the case of trafficking in persons (TPPO) and sentenced to pay restitution to 13 former crew of foreign ships from Myanmar who working at PT. PBR with a total refund of Rp. 884,000,000, - (eight hundred eighty-four million rupiah). ${ }^{3}$

Based on data from the Indonesian Police Criminal Investigation Agency (Bareskrim Polri), from 20112013 there were 467 cases of trafficking in persons. The majority of the 217 cases were economic exploitation, 215 were sexual exploitation, 29 cases worked were not in accordance with the agreement and 6 cases were traded. The majority of victims were 397 adult women, followed by 197 girls. The adult male victims numbered 114 adults and 1 boy. The number of victims is due to the position of Indonesia with a relatively large population but minimal availability of jobs plus limited quality of human resources is a factor in the number of victims who choose to work abroad which are promised to be highly paid by the perpetrators in order to exploit victims. ${ }^{4}$ Still from the Bareskrim Polri data, in 2015 there were 221 new case investigations and decreased compared to the previous year with 305 cases. The police handed over 165 cases to the higher prosecution stage compared to 134 cases in 2014, but it was not known how many prosecutions had been carried out. The Supreme Court sentenced 119 convicts in 2015, with prison sentences varying from 3 to 15 years, up from 79 convicts in $2014 .^{5}$

In South Sulawesi, until 2015, trafficking crimes were classified as high, with 422 people becoming victims of trafficking, where poverty, ignorance and damaged mentality were the main factors in the high human trafficking cases in South Sulawesi. More than $90 \%$ of prostitutes who have been recorded by the South Sulawesi Provincial Social Service apparently started from victims of trafficking. ${ }^{6}$ In the process of law enforcement (criminal justice) the victim of a crime is represented by the state through law enforcement officials to try and impose criminal sanctions on the defendant. Victims of criminal acts/crimes cannot immediately take

\footnotetext{
${ }^{1}$ Kadarudin, Keterkaitan Antara Stateless Persons, Pencari Suaka, dan Pengungsi, Jurnal Pengembangan Ilmu Hukum "Gratia” Volume VIII Nomor 1 Edisi April 2012, Kopertis Wilayah IX Sulawesi. p. 106

${ }^{2}$ See $h t t p: / / w w w . j p n n . c o m / n e w s / t k w$-gantung-diri-di-malaysia-ternyata-ini-komplotan-penjualnya. accessed on 13 November 2016.

${ }^{3}$ See http://www.dw.com/id/8-orang-divonis-3-tahun-penjara-dalam-kasus-benjina-tual/a-19111454. accessed on 13 November 2016.

${ }^{4}$ See http://www.kpai.go.id/artikel/temuan-dan-rekomendasi-kpai-tentang-perlindungan-anak-di-bidang-perdagangan-anak-trafficking-daneksploitasi-terhadap-anak. accessed on 13 November 2016.

http://print.kompas.com/baca/sains/iptek/2015/08/24/Perdagangan-Orang-di-indonesia -Masih -Tiga-Besar-Dunia. accessed on 13 November 2016.

${ }^{6}$ See Makassar.tribunnews.com/2015/08/20/ini-penyebab-korban-human-trafficking-marak-di-sulsel. accessed on 13 November 2016.
} 
their rights without going through a judicial process, so the fulfillment of victims' rights must also go through court decisions. Although in the Criminal Procedure Code (KUHAP) regulates the rights of victims but not as much as setting the rights of suspects and defendants.

Crime victims who are basically the ones who suffer the most in a criminal act, actually do not get as much protection given by the law to perpetrators. As a result, when the perpetrators of crimes have been sentenced to criminal sanctions by the court, the condition of victims of crimes is not cared at all. Even though the issue of justice and respect for human rights does not only apply to criminals, but also victims of crime. ${ }^{1}$ Criminal orientation which tends to focus on the perpetrator as an attempt to punish and deterrent effects will only have implications for not realizing the recovery of victims' rights and further adding to their suffering. Losses suffered by victims of this crime can be classified into 2 , namely material losses such as not fulfilling their rights after being treated as workers, and immaterial losses can be physical and psychological trauma and other negative impacts. Both of these losses generally suffer for victims of trafficking in persons.

Law No. 21 Year 2007 concerning Eradication of Criminal Acts on Trafficking in Persons has guaranteed the fulfillment of the rights of victims of TPPO which among them are:

a. The right to get personal protection from threats that endanger themselves, their souls and/or property (Article 47)

b. The right to get restitution (Article 48).

c. The right to get health rehabilitation, social rehabilitation, repatriation and social reintegration from the government (Article 51).

d. Victims who are abroad are entitled to be protected and repatriated to Indonesia at state expense (Article 54).

Fulfillment of the rights to victims as stipulated in the PTPPO Law is a contribution to the protection of victims' rights in the criminal justice process and is not merely oriented towards punishing the perpetrators. Just as the victim has the right to restitution or the right to claim compensation for loss of wealth or income, suffering, the cost of medical or psychological care or other compensation suffered by the victim as a result of being a victim of trafficking in persons. If referring to the PTPPO Law, the judicial process is not limited to being oriented towards punishing the perpetrators but also benefiting victims of crime. Like the victim has the right to restitution or the right to demand payment of compensation to the perpetrator for loss of property, physical or psychological suffering as a result of being a victim of trafficking in persons.

Even though it has become the victim's right, the provision of restitution cannot immediately be fulfilled, because restitution is paid based on a permanent legal decision (inkracht van gewijsde) through the criminal justice process. Because it depends on court decisions, restitution must be a concern. This concern originated from police investigations, included in the demands of the public prosecutor. Judges can also decide penalties for perpetrators of criminal acts of trafficking in persons with imprisonment and restitution.

Unlike the victims of crime, convicts have many legal institutions as a means of preventive and repressive legal protection. The Indonesian criminal justice system does not open the space for victims and the public to voice and fight for their interests, except in cases of convicts which contain additional criminal penalties in the form of compensation such as in cases of criminal trafficking in persons. ${ }^{2}$ The interests of victims and the public are represented by state apparatus called the Public Prosecutor (JPU). Thus, legal institutions that can be used as a means of preventive and repressive legal protection by victims and the public are the rights and obligations of prosecutors such as submitting a requisittoir (criminal charges), submitting an answer to the defense expressed by the defendant and appeal. ${ }^{3}$

Although victims and the public have been represented by prosecutors, the role of prosecutors as representatives of the public interest may not fully provide preventive legal protection for victims of crime. It could be that prosecution by the Prosecutor is not in line with the wishes of the victims and their families. It could even be possible that the victim was harmed by the prosecutor's actions, as a result, even though the perpetrators had been punished, the conflict between the two parties had not yet ended. ${ }^{4}$ Based on the explanation, the problem that will be discussed in this paper is how is the legal protection in the investigation process? and how is the identification and fulfillment of victims of trafficking rights?

\section{Research Method}

This type of research is normative legal research ${ }^{5}$ equipped with empirical data, this study uses a statutory

\footnotetext{
${ }^{1}$ Mansur, D \& Gultom, E. Urgensi Perlindungan Korban antara Norma dan Realita. Jakarta, Raja Grafindo Persada, 2007, p. 24

${ }^{2}$ Bambang Sugeng Rukmono, Ringkasan disertasi, Esensi Hukuman Terhadap Pelaksanaan Putusan Hukuman Mati dalam Perspektif Hak Asasi Manusia, Universitas Hasanuddin, 2015, p. 24-25.

${ }^{3}$ Ibid.

${ }^{4}$ Ibid.

${ }^{5}$ Soerjono Soekanto and Sri Mamudji, Penelitian Hukum Normatif; Suatu Tinjauan Singkat, Rajawali Press, Jakarta. 2004, p. 13-14
} 
approach and a case approach. ${ }^{1}$ The data used are secondary data collected through interviews and documentation studies. The collected data is then analyzed qualitatively.

\section{Results and Discussion}

Crime which is a classic problem of humanity in its social environment so that by Benedict A. Alper termed crime as the oldest social problem. ${ }^{2}$ In efforts to combat crime or also known as the term "criminal politics" according to G.F. Heofnagels can be reached in 3 ways, namely: ${ }^{3}$

a. Application of criminal law application.

b. Prevention without crime (prevention without punishment).

c. Influence the public's view of crime and punishment through mass media (influencing views of society on crime and punishment/mass media).

Of the three ways found by G.F. Heofnagels above can be understood that there are 2 pathways in efforts to overcome crime, namely through the reasoning path, namely by the application of criminal law and nonreasoning pathways, namely without using criminal law and influencing the public's view of crime by knowing the factors that cause crime. Non-reasoning efforts can be a key and strategic position in overcoming the causes and conditions that cause crime. ${ }^{4}$ The line of reason is repressive (preventive/eradication) and non-reason is preventive (prevention/control) before the occurrence of crime. ${ }^{5}$ In the context of the protection of victims of crime, there are preventive and repressive measures carried out, both by the public and the government (through law enforcement officers), such as the provision of protection/supervision from various threats that can endanger the lives of victims, provide medical assistance, or legally adequately, the examination process and fair trial against perpetrators of crime, basically is one manifestation of the protection of human rights and balancing instruments. $^{6}$

People smuggling and illegal immigrants are interrelated criminal acts. Such activities can occur if one of them can be realized, in the sense that illegal immigrants will succeed with the conspiracy of smuggling agents, and people smugglers resulting in an increasing number of illegal immigrants. ${ }^{7}$ Trafficking crimes that can affect anyone including women and children who are potential targets of economic and sexual exploitation. Including in South Sulawesi, according to data from the Office of Women's Empowerment and Protection of South Sulawesi's Children for trafficking in 2017 there were 11 women and children who were victims and 8 people in 2018 .

Especially for trafficking which often befall women and children by Messy Papuyungan stated that ${ }^{8}$ human trafficking is increasingly prevalent because it is covert and illegal. The data is qualitatively difficult to obtain and what appears on the surface are only cases that are reported directly to the authorities or through P2TP2A. As for the forms of trafficking in general that often appear on the surface such as:

a. To be a prostitute.

b. To be employed on jermal (fishing in the middle of the sea).

c. As organized beggars.

d. As a housemaid with long working hours.

e. Adoption.

f. Marriage with foreign men for the purpose of exploitation.

g. Pornography.

h. Drug dealers.

i. Become a pedophile victim.

The risk factors for trafficking are ${ }^{9}$

a. Poverty.

b. Low education.

\footnotetext{
${ }^{1}$ Peter Mahmud Marzuki, 2005, Penelitian Hukum, Prenadamedia Group Jakarta, p. 35

${ }^{2}$ Widiartana, 2014. Viktimologi, Perspektif Korban dalam Penanggulangan Kejahatan, Cahaya Atma Pustaka, Yogyakarta, p. 55.

${ }^{3}$ Barda Nawawi, 2008, Masalah Penegakan Hukum dan Kebijakan Hukum Pidana dalam Penanggulangan Kejahatan, Kencana, Jakarta, p. $41-42$.

${ }^{4}$ The strategy to prevent crime by having to eliminate the causes of crime and be seen in various UN congresses on "the prevention of crime and treatment of offenders" such as (1) the $6^{\text {th }}$ UN Congress in 1980 in Caracas, Venezuela on "Crime tends and crime prevention strategies "; (2) The $7^{\text {th }}$ UN Congress in 1985 in Milan, Italy concerning "Crime prevention in the context of development"; (3) The $8^{\text {th }}$ UN Congress in 1990 in Havana, Cuba regarding "Social aspects of crime prevention and criminal justice in the context of development".

${ }^{5}$ Barda Nawawi, 2008, Op.cit.

${ }^{6}$ Dikdik. M. Arief Mansur, 2007. Urgensi Perlidungan Korban Kejahatan Antara Norma dan Realita. PT. Raja Grafindo Persada. Jakarta, p. 161

${ }^{7}$ Kadarudin, People Smugling Dalam Perspektif Hukum Internasional dan Penegakan Hukumnya di Indonesia, Jurnal Perpustakaan, Informasi dan Komputer "Jupiter" Volume XII Nomor 2 Edisi Juni 2013, UPT. Perpustakaan Universitas Hasanuddin. p. 69-70

${ }^{8}$ Head of the Regional Technical Implementation Unit (UPTD) Integrated Service Center for Women and Children Protection (P2TP2A) South Sulawesi in an interview on December 6, 2018.

${ }^{9}$ Ibid.
} 
c. Unemployment.

d. Migration out of the village and abroad

e. Fragile family resilience.

f. Factors of male and female inequality (gender) and patriarchal culture.

g. Consumerism.

h. Encouragement of broadcasting and pornographic writing in the mass media.

i. Law enforcement against perpetrators is still not firm and consistent.

j. Public and government awareness about trafficking is not sufficient.

In this study the meaning of the victim is defined in the narrow sense as a victim of crime, namely the victim of crime regulated in the provisions of criminal law. ${ }^{1}$ A person who has suffered losses as a result of a crime and/or whose sense of justice has been directly disturbed as a result of his experience as a target of crime. ${ }^{2}$ The suffering that he experienced was both mental, physical, material, and non-material suffering. ${ }^{3}$ Because victims are the result of a crime that has been determined in criminal law, victims who are deprived of their human rights must always be recognized, respected and protected, including through various legislative products. ${ }^{4}$ Thus in the protection of victims of crime there are 2 models of protection, namely: ${ }^{5}$

a. Model procedural rights (the procedural rights model). In brief, this model emphasizes the possibility of active participation of victims in criminal justice processes such as helping public prosecutors, involved in each level of case examinations, whose opinions must be heard if the convict is released on parole, and so on.

b. The services model which emphasizes the provision of compensation in the form of compensation, restitution and efforts to retrieve the condition of victims who experience trauma, fear and pressure due to crime.

From the two models above, in providing legal protection to the public and especially victims of crime, it is not enough to apply imprisonment and criminal penalties to the perpetrators but many victims' rights that must be protected especially in the course of the criminal justice system. Because the criminal justice system should not only follow up on reports of victims of crime by completing it until the stage of the court session by deciding the criminal offender but must be able to realize the rights of the victims of the crime. As Muladi stated that in the regulatory concept of protecting victims of criminal acts, the first thing to consider is the essence of the losses suffered by victims. The essence of the loss is not only material or physical suffering but also psychological. $^{6}$

Therefore, the police, prosecutors, judges, advocates as part of the criminal justice system have an important role in providing protection to victims of trafficking in persons with duties and responsibilities based on existing laws and regulations, such as:

a. The police have a role in providing legal protection as stipulated in Law Number 2 Year 2002 concerning the Police of the Republic of Indonesia which can be divided into 2 types of protection, namely preventive protection and repressive protection. Preventive protection in the form of preventive measures for symptoms before the occurrence of a crime while preventive protection in the form of investigation and investigation of all criminal acts in accordance with criminal procedural law and other laws and regulations.

b. The role of the prosecutor's office can be seen in Law Number 16 of 2004 concerning the Prosecutor's Office of the Republic of Indonesia. By carrying out prosecution, the prosecutor's office has tried to provide legal protection for victims of crimes committed by the perpetrators. Especially when the prosecutor's office seeks to accommodate the interests of the victims demanding compensation as a result of the perpetrators' evil deeds.

c. The judge also has a role in legal protection efforts against. So, in the trial process the judge not only focuses his attention on fulfilling the rights of the defendant, but helps justice seekers and tries to overcome all obstacles and obstacles to achieving a simple, fast, and low-cost justice system. What is meant by justice seekers is victims of crime. (Article 4 of Law Number 48 Year 2009 concerning Judicial Power).

d. The advocate's role provides legal assistance to victims of trafficking in persons in investigations, prosecutions and hearings in court proceedings as an effort to ensure the fulfillment of the rights of victims of trafficking in accordance with existing laws and regulations. Paying attention in the form of legal assistance to justice seekers is an obligation for advocates, especially those who cannot

\footnotetext{
${ }^{1}$ Lilik Mulyadi, Kompilasi Hukum Pidana dalam Perspekrif Teoritis dan Praktik Peradilan Pidana, Mandar Maju, Bandung, 2010, p. 1.

${ }^{2}$ Muladi dan Barda Nawawi Arief, 2007. Bunga Rampai Hukum Pidana, PT. Alumni, Bandung, 2007, p. 84

${ }^{3}$ Bambang Waluyo, 2011. Viktimologi Perlindungan Korban dan Saksi, Sinar Grafika, Jakarta, p. 11

${ }^{4}$ Dikdik M. Arief, Op.cit., p. 157

${ }^{5}$ Barda Nawawi Arief, Beberapa Aspek kebijakan Penegakan dan Pengembangan Hukum Pidana. Citra Aditya Bakti, Bandung, 1998 , p. 58

${ }^{6}$ Muladi, 1995. Kapita Selekta Sistem Peradilan Pidana, Badan Penerbit Universitas Diponegoro, Semarang, p. 177
} 
(Article 22 paragraph 1 of Law No. 18 Year 2003 concerning Advocates).

e. In addition to the law enforcement agencies above, the presence of the Witness and Victim Protection Agency (LPSK) which was formed based on Law Number 13 of 2006 concerning the Protection of Witnesses and Victims, has a very important role in the context of law enforcement and protection of witnesses and victims. LPSK institutions must carry out their duties, functions, and authorities in synergy with the duties, functions and authority of law enforcement agencies within the criminal justice system.

The criminal justice system as a system will maintain the balance of protection of interests, both the interests of the state, the interests of the community, and individual interests, including the interests of criminal offenders and victims of crime. In the implementation of legal protection for victims of trafficking in the course of the criminal justice system, it cannot be separated from the role of the sub-criminal justice system itself in guarding the fulfillment of victims' rights which have been regulated in such a manner.

Montesquieu states that a good form of legislation must allow prevention of crime rather than punishment. ${ }^{1}$ In the perspective of the criminal law policy the purpose of criminal law is not limited to regulating the actions of the people but also regulates actions in the authority of law enforcement officials. The Criminal Procedure Code has regulated a system of supervision and accountability to uphold the creation of an integrated criminal justice system and its implementation must also synchronize laws and regulations regarding the duties and authority between system components in the criminal justice system.

By that, it is known as the principle of functional differentiation which is an affirmation of the division of tasks, functions and authorities of each law enforcer institutionally as in the provisions of Article 1 number 1 to 5 of the Criminal Procedure Code for investigation and investigation assignments, Article 1 numbers 6 to 7 and Article 13 to Article 15 of the Criminal Procedure Code for the duties of public prosecutors. The functions and authorities have been arranged in such a way as to continue to pay attention to the correlation and coordination in the interrelated and continuous law enforcement process between one institution and another institution starting from the investigation phase to the implementation of the court's decision.

\section{A. Legal Protection in the Process of Investigation}

Moeljatno's formulation indicates that criminal law is a set of rules governing 3 elements, namely the rule of crime, criminal liability and the verbal process of law enforcement if a crime occurs. This element shows the relationship between material criminal law and formal criminal law, which means that violations of the material criminal law will have no meaning without the establishment of formal criminal law (criminal procedure law). Similarly, the formal criminal law cannot function without violating the norms of material criminal law. ${ }^{2}$ Investigation is a series of actions / investigations to find and find an event that is suspected of being a criminal offense to determine whether or not an investigation can be carried out according to the manner in this law (Article 1 Item 5 of the Criminal Procedure Code).

From the above understanding it can be understood that the investigation was carried out before the investigation. It should be underlined looking for and finding an event that is suspected of being a crime. The goal of "finding" is "finding" means the investigator is trying on his own initiative to find an event that is suspected of being a criminal offense. However, in everyday reality, investigators usually begin to carry out their duties after the report/complaint from the aggrieved party. ${ }^{3}$ Whereas investigation is a series of investigator's actions in terms of and according to the method stipulated in this law to search for and collect evidence that with evidence makes it clear about the crime that occurred and to find the suspect (Article 1 point 2 of the Criminal Procedure Code). From the above understanding, it can also be understood that the investigator has 2 main tasks, namely (a) searching for and collecting evidence that with the evidence makes light about the crime that occurred, and (b) found the suspect.

Yahya Harahap said that before the investigation was carried out, an investigation was carried out by investigating officials, with the intent and purpose of collecting preliminary evidence or sufficient evidence so that further investigation could be carried out. Investigations can be equated with the notion of an act of investigation as an effort to find and find traces in the form of information and evidence of an event that is alleged to be a criminal act. ${ }^{4}$ So if we pay close attention to the motivation and purpose of the investigation, it is a demand of responsibility to the investigating apparatus, not to carry out law enforcement actions that demean human dignity. Before proceeding to carry out an examination of investigations such as arrest or detention, you must first try to collect facts and evidence, as a basis for follow-up investigations. ${ }^{5}$

During the investigation phase, the police acting as investigators try to find and find an event that is

\footnotetext{
${ }^{1}$ Muhadar dan Audyna Mayasari Muin, Kriminologi (Suatu Pengantar), Makassar: Pusat Kajian Media dan Sumber Belajar, LKPP Universitas Hasanuddin, 2016, p. 3; see also A.S. Alam, 2010, Pengantar Kriminologi, Makassar: Pustaka Refleksi Books, p. 10-11

${ }^{2}$ Andi Sofyan and Nur Azisa, Hukum Pidana, Makassar: Pustaka Pena Press, 2016, p. 3

${ }^{3}$ Leden Marpaung, Proses Penanganan Perkara Pidana (Penyelidikan dan Penyidikan), Sinar Grafika, Jakarta, 2011, p. 6

${ }^{4}$ M. Yahya Harahap, Pembahasan Permasalahan dan Penerapan KUHAP Penyidikan dan Penuntutan. Sinar Grafika, Jakarta, 2006, p. 101.

${ }^{5}$ Ibid., p. 102
} 
suspected of being a criminal offense to determine whether or not an investigation can be conducted (Article 4 12 KUHAP). So that this investigation is the initial stage of the investigation. But that does not mean that the investigation is an independent action and separate from the investigation but both are inseparable parts of the investigation function. Based on the Guidelines for the Implementation of the Criminal Procedure Code, investigation is one method or sub-function of investigation that precedes other actions, namely prosecution in the form of arrest, detention, search, confiscation, examination of letters, summons, acts of examination and submission of files to the public prosecutor.

In order to investigate, the investigator has the authority to do a number of things as stipulated in Article 7 of the Criminal Procedure Code, namely:

a. Receive reports or complaints from a person about a crime;

b. Take the first action when on the scene;

c. Order to stop a suspect and examine the suspect's personal identification;

d. Carrying out arrest, detention, search and seizure;

e. Conduct inspection and seizure of letters;

f. Taking fingerprints and photographing a person;

g. Call people to be heard and examined as suspects or witnesses;

h. Bring in experts who are needed in connection with the case examination;

i. Hold a termination of investigation;

j. Conduct other actions according to the law that are responsible.

In carrying out investigative and investigative duties, the police must comply with the constitution precisely in Article 30 paragraph (4) of the 1945 Constitution of the Republic of Indonesia explaining the National Police of the Republic of Indonesia as a state instrument that maintains security and public order to protect, protect, serve the community, and uphold the law. Article 13 of Law Number 2 Year 2002 concerning the National Police of the Republic of Indonesia affirms the main duties of the police, namely (1) maintaining security and public order, (2) enforcing the law, and (3) providing protection, protection and service to the community.

From the obligation of investigators based on Article 7 of the Criminal Procedure Code it can give an idea of the position of victims of crime at the stage of investigation. When a report or complaint gets a response from the investigator by investigating, the existence of the victim is very much needed to be able to give his statement as a victim witness to strengthen the suspicion of the involvement of the perpetrator in a criminal act. In this case the role of the victim giving his statement in front of the investigator is very necessary to be able to proceed or not the criminal process against the perpetrator, although in giving his testimony/testimony, the victim can only be passive. Victims are no more than just witnesses who can only explain or tell all questions when asked by investigators. The investigation was carried out to find and gather evidence that with evidence that made light about the criminal acts of trafficking that occurred. In the investigation of criminal acts of trafficking in persons, investigators identify the crime of trafficking in persons. ${ }^{1}$

\section{B. Identify and Fulfill the Victim's Rights of Trafficking in Persons}

Identification of victims of human trafficking crimes is carried out in response to reports from victims, families, or other people of the crime of trafficking in persons (TPPO). The response is a standard for conducting trafficking investigations in which victims are identified and then questioned for the crime of trafficking in persons they have experienced. The next stage carried out by investigators is collecting evidence found directly from the victim or found in the field.

The initial action of the investigation phase is very important in identifying whether TPPO has occurred or not. If a criminal act actually occurs, the investigation has a key role in the success of prosecution by the Public Prosecutor. The importance of this investigation, the victim must be given full attention because through the statements of the victim, comprehensive information about TPPO can be obtained.

The effectiveness of the investigation will not be achieved if the victim does not openly give his statement, so that services and protection are needed. This is the basis for the issuance of the Head of the Indonesian National Police Regulation Number 3 of 2008 concerning the Establishment of Special Service Spaces and Procedures for Examining Witnesses and/or Victims. This is a concrete manifestation of the protection of witnesses and victims in the investigation phase. In identifying victims of trafficking through the following phases:

a. Initial identification, which indicates there is an indication that someone has become a victim of trafficking. This identification can be done by anyone who is associated with someone who is suspected of being a victim. The results of this identification will be the basis for reporting to the authorities.

b. Allegations that the indicators of someone who has become a victim of trafficking have been

\footnotetext{
${ }^{1}$ Identification of the occurrence of criminal acts of trafficking begins when there is a report of the reporting witness or the victim himself. This identification is a procedural step taken by the police so that it can easily generate available evidence.
} 
fulfilled. Therefore, victims must be given access to initial assistance and protection.

c. Verify that someone is a victim of trafficking by the authorities. This is a determining factor whether the person concerned has the right to obtain more comprehensive assistance and protection. This is very important for the process of investigation and prosecution for traffickers.

Protection in the criminal justice process aims to empower victims to be able to freely testify optimally by ensuring that victims get adequate protection and support. As was done by the Reskrimum Women's and Children's Protection Unit (PPA) of the South Sulawesi Regional Police, which seeks to pay attention to all victims' needs for assistance and protection in the form of fulfilling the rights of victims as stipulated in legislation, as well as:

a. Victims were placed in a Special Service Room (RPK) by placing female police officers so that victims could calmly and openly give their statements. In the Special Service Room (RPK), which is a special closed and comfortable room in the Police unit, where women and children who are victims of trafficking can report their cases safely to the Policewoman who is empathetic, understanding and professional.

b. Avoiding questions that can corner the victim as if the victim was the cause of the crime. questions that corner the victim can certainly have a psychological impact on the victim.

c. Victims who experience trauma or psychological disorders, it is necessary that investigators establish cooperation with other institutions such as the Integrated Service Center for Women and Children Protection (P2TP2A) to provide counseling to victims and other services.

d. Providing information about what happened and how long the trial process will take place. Providing information to victims or their families regarding the process of investigating and examining criminal acts experienced by victims has an important role in the effort to make the community as partners of the police because this information can also be a public control of the police's performance can be effective.

e. Get support during interrogation and trial by utilizing all existing protections for victims and witnesses.

f. Given the widest possible access to assistance, legal assistance, demands for restitution, rehabilitation.

g. Protected from all kinds of threats, any intimidation of victims and families.

h. Not making unnecessary contact with the suspect includes not being in the same room as the suspect during the investigation

Witnesses or victims who are asked to provide information on all stages of the examination, become a necessity that guarantees are free from threats must be accompanied by a guarantee that the person is free from fear, threats, intimidation or all those who make witnesses or victims uncomfortable especially when giving their statements. This guarantee is solely so that the witness or victim can provide information in truth about a criminal case that he himself heard, he saw for himself and he experienced it himself. The obligation to guarantee security as stipulated in Law No. 13 Year 2006 which was later revised to Law No. 31 Year 2014 concerning Amendments to Law No. 13 Year 2006 concerning the Protection of Witnesses and Victims.

From several cases of criminal acts of trafficking that occurred in the South Sulawesi Regional Police, sometimes there are victims of trafficking who do not realize that they have become victims or feel that they have not been exploited because their work was carried out on their own volition and without intimidation and coercion. Nevertheless, the victim's information is still included in the Minutes of Examination, because basically in cases of criminal acts of trafficking does not require the consent of the victim. Because even if exploitation occurs, no one will approve the exploitation of it. By digging up information from the victim, the investigator can find out more about the crime of trafficking in persons.

The indicators that can generally be used to identify situations that lead to trafficking in persons, such as: (1) The victim has been deceived for the actual conditions he is living in, (2) The victim does not receive a salary, or only receives a little of what he should receive, (3) Victims are forced to remain in trafficking situations, and (4) Victims are forced to work far beyond normal working hours. ${ }^{1}$

In addition, there are also specific indicators that often afflict victims of trafficking, for example (1) Victims are sexually exploited by fraud, coercion and threats, (2) Victims are sexually exploited (prostitution) without coercion and self-will, (3) Victims living in an improper place, such as a factory to be forcibly employed, (4) Victims are not allowed to leave their place of residence or socialize with their surroundings, (5) Victims experience persecution, harassment, threats and violence, (6) Victims are forced to approve or hold marriage, and (7) Victims are used by third parties to obtain profits in the form of cash or dowry through the marriage of

\footnotetext{
${ }^{1}$ This indicator is based on several cases that researchers observe with different modes. As was done by A. Ika Purnama Sari, so was Rosmiti Binti Andi Sirajuddin who deceived and deceived her victims into working in Malaysia with a job as a hotel maid but upon arrival in Malaysia victims were employed as Household Assistants with wages that were not previously promised, working in excess of normal working hours, treated inhumane, physically tortured, even treated in a hospital.
} 
the victim. ${ }^{1}$

\section{Conclusion}

Article 7 of the Criminal Procedure Code illustrates that when a report or complaint receives a response from an investigator by investigating, the existence of the victim is urgently needed to be able to provide testimony as a victim witness to strengthen the suspicion of the involvement of the perpetrator in a criminal act. In this case the role of the victim giving his statement in front of the investigator is very necessary to be able to proceed or not the criminal process against the perpetrator, although in giving his testimony, the victim can only be passive. Victims are no more than just witnesses who can only explain or tell all questions when asked by investigators. The investigation was carried out to find and gather evidence that with evidence that made light about the criminal acts of trafficking that occurred. In the investigation of criminal acts of trafficking in persons, investigators identify the crime of trafficking in persons. The indicators that can generally be used to identify situations that lead to trafficking in persons, such as: (1) The victim has been deceived for the actual conditions he is living in, (2) The victim does not receive a salary, or only receives a little of what he should receive, ( 3 ) Victims are forced to remain in trafficking situations, and (4) Victims are forced to work far beyond normal working hours.

\section{References}

A.S. Alam, 2010, Pengantar Kriminologi, Makassar: Pustaka Refleksi Books.

Andi Sofyan and Nur Azisa, Hukum Pidana, Makassar: Pustaka Pena Press, 2016.

Badan Pendidikan dan Pelatihan Kejaksaan Republik Indonesia, 2014. Modul Trafficking.

Bambang Sugeng Rukmono, Ringkasan disertasi, Esensi Hukuman Terhadap Pelaksanaan Putusan Hukuman Mati dalam Perspektif Hak Asasi Manusia, Universitas Hasanuddin, 2015.

Bambang Waluyo, 2011. Viktimologi Perlindungan Korban dan Saksi, Sinar Grafika, Jakarta.

Barda Nawawi, 2008, Masalah Penegakan Hukum dan Kebijakan Hukum Pidana dalam Penanggulangan Kejahatan, Kencana, Jakarta.

Barda Nawawi Arief, 2008, Beberapa Aspek kebijakan Penegakan dan Pengembangan Hukum Pidana. Citra Aditya Bakti, Bandung.

Dikdik. M. Arief Mansur, 2007. Urgensi Perlidungan Korban Kejahatan Antara Norma dan Realita. PT. Raja Grafindo Persada. Jakarta.

http://www.jpnn.com/news/tkw-gantung-diri-di-malaysia-ternyata-ini-komplotan-penjualnya. Accessed on November 3, 2016.

http://www.dw.com/id/8-orang-divonis-3-tahun-penjara-dalam-kasus-benjina-tual/a-19111454. Accessed on November 3, 2016.

http://www.kpai.go.id/artikel/temuan-dan-rekomendasi-kpai-tentang-perlindungan-anak-di-bidangperdagangan-anak-trafficking-dan-eksploitasi-terhadap-anak. Accessed on November 3, 2016.

http://print.kompas.com/baca/sains/iptek/2015/08/24/Perdagangan-Orang-di-indonesia-Masih -Tiga-BesarDunia. Accessed on November 3, 2016

http://news.rakyatku.com/read/98220/2018/04/24/dpppa-makassar-gulung-sindikat-trafficking-bermodus-uangpanai. Accessed on November 3, 2016.

Kadarudin, Keterkaitan Antara Stateless Persons, Pencari Suaka, dan Pengungsi, Jurnal Pengembangan Ilmu Hukum "Gratia” Volume VIII Nomor 1 Edisi April 2012, Kopertis Wilayah IX Sulawesi.

Kadarudin, People Smugling Dalam Perspektif Hukum Internasional dan Penegakan Hukumnya di Indonesia, Jurnal Perpustakaan, Informasi dan Komputer "Jupiter" Volume XII Nomor 2 Edisi Juni 2013, UPT. Perpustakaan Universitas Hasanuddin.

Leden Marpaung, Proses Penanganan Perkara Pidana (Penyelidikan dan Penyidikan), Sinar Grafika, Jakarta, 2011.

Lilik Mulyadi, Kompilasi Hukum Pidana dalam Perspekrif Teoritis dan Praktik Peradilan Pidana, Mandar Maju, Bandung, 2010

Peter Mahmud Marzuki, 2005, Penelitian Hukum, Prenadamedia Group Jakarta.

M. Yahya Harahap, Pembahasan Permasalahan dan Penerapan KUHAP Penyidikan dan Penuntutan. Sinar Grafika, Jakarta, 2006.

Mansur, D \& Gultom, E. Urgensi Perlindungan Korban antara Norma dan Realita. Jakarta, Raja Grafindo Persada, 2007.

Makassar.tribunnews.com/2015/08/20/ini-penyebab-korban-human-trafficking-marak-di-sulsel. Accessed on

${ }^{1}$ The indications of trafficking were based on panoramas, where a girl with the initials NS was married to her sister-in-law in East Kalimantan with a contractor, then after her money in her hand and her marriage took place then her sister-in-law tried to find a problem so that NS and the contractor divorced. Interview with Makmur respondents as social facilitators at PTP2A, Makassar City. Related news can also be accessed http://news.rakyatku.com/read/98220/2018/04/24/dpppa-makassar-gulung-sindikat-trafficking-bermodus-uang-panai. 
November 13, 2016.

Muhadar and Audyna Mayasari Muin, Kriminologi (Suatu Pengantar), Makassar: Pusat Kajian Media dan Sumber Belajar, LKPP Universitas Hasanuddin, 2016.

Muladi, 1995. Kapita Selekta Sistem Peradilan Pidana, Badan Penerbit Universitas Diponegoro, Semarang.

Muladi dan Barda Nawawi Arief, 2007. Bunga Rampai Hukum Pidana, PT. Alumni, Bandung, 2007.

Soerjono Soekanto and Sri Mamudji, Penelitian Hukum Normatif; Suatu Tinjauan Singkat, Rajawali Press, Jakarta. 2004.

Widiartana, 2014. Viktimologi, Perspektif Korban dalam Penanggulangan Kejahatan, Cahaya Atma Pustaka, Yogyakarta.

Workshop on the Implementation of the Trafficking in Persons Crime Act implemented by Australia Indonesia Pertnership for Justice (AIPJ) with the Government of South Sulawesi Province in Makassar on 12-13 March 2015, See https://indonesia.embassy.gov.au/jaktindonesian/AR15-005.html 